\title{
TRANSLATING UNTRANSLATABLE IN LITERARY NARRATIVES: BROADENING THE INTERPRETATION SCOPE
}

Summary. The article discusses the challenges and pitfalls of narrative text translation in the interpretative framework aiming at modeling translation activities. The approach is grounded on major cognitive procedures and highlights effective ways to translate culture specific language elements to ensure translation adequacy and equivalence via the relevant choice of translation strategies and techniques.

Current translation studies emphasize the interpretational potential of conceptual, semiotic, and linguistic aspects of the alternative world model of the literary text that necessitates the use of accurate verbal representation of ethnic and cultural specificity of a certain language that is predetermined by the conceptualization and categorization particularities of the nation's world perception.

The cognitive approach is used in the article to interpret temporal expressions in the literary narrative to determine the particularities of actualization of the temporal parameter regarded as a key aspect of the alternative text world. Special emphasis is put on the culture specific linguistic devices used to create the illusion of time 'flow' of text events and of temporal location of textual situations, both of which constitute the basis of the world model of the narrative. Conceptual and theoretical assumptions in the framework of modern translation studies helps to enhance a systematic study of textual world parameters with regard to the specificity of representation of lingual and cultural features of a particular language in the fiction world of the literary narrative. Taking into consideration mental constructs in translation results in the right choice of interpretive tools that provide adequate perception of pragmatic and aesthetic settings of the source text.

We believe it is logical to claim that conceptual integration principles are to be employed in the translation process to ensure semantic and pragmatic modification of the source text to transfer its message into the target text in an adequate way, as application of the interpretative translation algorithm reinforces the efficacy of the system of special translation strategies and techniques that aim to ensure proper conveyance of the source text semantics and pragmatics.

Key words: interpretative cognitive translation model, literary narrative, conceptual element, culture specific element, text alternative world model, translation strategy.

Introduction. Much has been written about the challenges in translating culture specific lexical elements in different linguistic paradigms many of these being considered untranslatable due to their unique meanings. Still, the enigma of explaining the processes and procedures behind making the target text (TT) as aesthetically valuable as the source text (ST) calls for further studies to provide understanding of the mechanisms behind adequacy and efficacy of complex multifaceted and multidimensional transfer of concep- tual specifics of the original text. The research repertoire of modern translation studies is expanding due to the focus on the achievements of cognitive science. Thus, translational studies should take into account the peculiarities of obtaining, processing, storing and using verbalized knowledge. The problem of comprehending the ST and the TT and creating a cognitive model of their translation as a result of interpretation of their semantic and pragmatic aspects is research of the key issues in translation studies.

Pivotal advances in the cognitive-pragmatic paradigm, that provide a solid study of linguistic expressions in discourse and text, outline new approaches to the research of cognitive, communicative and socio-cultural aspects of linguistic meanings and highlight the necessity of further investigation of the issues of universals vs uniqueness, simplification vs complication, extension vs limitation. Current translation studies aim to deepen the understanding of cognitive and linguistic aspects of translation in different social contexts so that to ensure correlation between the ST and the TT.

Recent research and publications. Fundamental assumptions of translation studies offered by M. Baker, S. Coulson, O. Todd, G. Fauconnier, M. Turner, G. Hansen, O. Rebrii A. Pym, G. Toury have shaped the current translation paradigm and methodological framework $[1 ; 3 ; 6 ; 7 ; 8 ; 9 ; 13]$. Despite numerous studies of diverse translation issues, the nature and particularities of meaning transfer call for the approach that will integrate findings from socio-linguistic sciences to address the problems of adequacy and equivalence between source and target texts $[5 ; 10 ; 12]$.

Translation procedures encompass analyses of particularities of knowledge structures, verbalized in the text, consideration of text social, cultural and conceptual dimensions, use of certain linguistic devices as well as interpretation and transference of the narrative content [2]. So, unique features of text pragmatics and semantics should be based on the theoretical postulates of cognitive translatology to ensure adequate translation choices. The aim of the article is to provide insights into the interpretative cognitive approach to literary narrative translation and to outline effective ways to ensure accurate meaning decoding of the temporal parameter in the ST to transfer its unique conceptual, pragmatic and communicative features into the TT.

Obviously, the transfer of the ST particularities into the TT is to match and fit the socio-cultural conventions of the target culture. In this regard, the main translation challenge is caused by the variety of figurative language means in the ST $[1 ; 10]$. It is the interpretative cognitive approach that offers new insights into the transfer of culture specific knowledge in translation via proper decoding of the ST conceptual dimension features. Thus, translatological analysis of literary narratives should be grounded on the interpretation of various meanings via an integrated approach to the trans- 
lation of the ST that ensures the transfer of the most important concepts and knowledge formats present in conceptual dimension of the ST verbalized by a system of multilevel language devices to convey its message accurately in the TT.

Discussion and rationale. In current translation studies the term 'untranslatable' is used regarding several ideas, a common one focuses mostly on the surface level of the text and others relate to the deep layer of conceptual dimension of the text, particularly those that relate to the translation of realia. As innovative translation practices are more focused on the complex relations between the ST and the TT, they do not aim at transferring the exact meaning of components beneath the surface structure of the ST. From this perspective the goal of the translation is not to create the TT that is exactly equivalent to the ST regardless of the aspects considered in terms of adequacy.

We share the opinion expressed by J. Derrida that the relation between original and translation is based not on resemblance, but on difference. The scientists states, 'Nothing can be wholly untranslatable or wholly translatable. The translatability is premised on what is untranslatable and vice versa. It is in the gaps arising from this conflict, that the traces that generate meaning emerge - perhaps not a closed meaning, but the possibility and promise of as well as a yearning for meaning. Just as untranslatability becomes a condition for translatability, 'mistranslation' is a condition for translation' [4, p. 178].

Given the postulate, the relation and correlation between the ST and the TT depend on the difference of the texts involved, that requires the use of transformation and modification in the translation process. We believe it logical to claim that there are at least two levels translators deal with, that is the surface level of the sentence/ text syntagmatics, present in the linear succession of language elements, and the deep level of the conceptual aspect every meaningful message or utterance has in its core. The complex procedure of transferring the conceptual into the linguistic dimension includes a number of stages that are governed by the cognitive, semantic, pragmatic, socio-cultural and language specific constraints. Thus, the complexity of translation job requires special knowledge and expert skills for translators not only to deal with the surface verbal representation but to cover and convey the message that is to be decoded properly but still to suit the national and cultural code of the target language context. So, by untranslatable we mean mainly the semiotics of the culture specific symbols that do not have equivalents in the target culture and thus call for a number of means to render corresponding ideas and convey particular meanings.

According to S. Zhabotynska and N. Slyvka, the main components of the text content are revealed in the linguo-cognitive formations, that are to be studied in the framework of conceptual analysis as the approach focuses on the scope of functional and semantic modification in a particular semantic system [14].

As the interpretative cognitive translation model takes into account different meanings and functions of the language units it proves effective so that to get insights into mechanisms of linguistic actualization of conceptual categories that are revealed through culture specific meanings in the literary narrative. Moreover, the interpretative algorithm provides adequate tools to ensure accurate transfer of realia, so it appears relevant for a successful intercultural transfer and reliable mechanisms for effective translation practices.

Let us consider the way temporal meanings are conveyed in translation. Time being a universal parameter it is represented in the language via a complex system of special temporal devices that are used in the literary narrative to reveal the particularities of the temporal aspect of the text through a set of temporal markers. Linguistic analysis of literary narratives proves that the temporal aspect of the text is elaborate in terms of variety and number of linguistic elements used to reveal time specificity, semantics and pragmatics of temporal devices used in the passage from the novel 'Swing Time' by a contemporary British author Zadie Smith.

The excerpt illustrates a multilayer overlapping of temporal aspects of different alternative worlds in the text continuum, namely the objective (real), author's and text (narrative), some of these having several sublayers as well.

Ours was the first graduating class to receive e-mail addresses, and my mother, always curious about new things, acquired a battered old Compaq, to which she attached a doddering modem. Together we entered this new space that now opened up between people, a connection with no precise beginning or end, that was always potentially open, and my mother was one of the first people I knew to understand this and exploit it fully. Most e-mails sent in the mid-nineties tended to be long and letter-like: they began and ended with traditional greetings - the ones we'd all previously used on paper - and they were keen to describe the surrounding scene, as if the new medium had made everybody a writer. ('I'm typing this just by the window, looking out to the blue-gray sea, where three gulls are diving into the water"). But my mother never e-mailed that way, she got the hang of it at once, and when I was only a few weeks out of college, but still that blue-gray sea, she began sending me multiple two- or threeline messages a day, mostly unpunctuated, and always with the sense of something written at great speed [11, 289-290].

The temporal dimension of the extract is represented by several constituting layers:

a) real time: in the mid-nineties, 'd previously used,

b) narrative time (localization): now, am typing, just, are diving,

c) narrative time (stretch / flow of time): no precise beginning or end, multiple two-or three-line messages a day,

d) succession of narrative events localized with the help of predicate tense forms and adverbial modifiers of time: at once, when, previously, still, always, never, was, acquired, entered, attached, e-mailed, got the hang, began,

e) character personal time: was the first graduating class to receive e-mail addresses, when I was only a few weeks out of college, but still that blue-gray sea.

To deal with untranslatable elements it is instrumental to explain the things that are no longer available or the ones that are so different from those readers are accustomed to that they are hard to comprehend. In the passage analyzed modern readers are unlikely to recognize the brand name Compaq due to its culture specific meaning as well as to grasp the idea of a doddering modem.

Some text specific elements require extra effort on the part of the translator to transfer their semantics adequately. For example, the meaning of the phrase but still that blue-gray sea is clear only with reference to the sentence when I was only a few weeks out of college, which in its turn is related to the explanatory sentence that does not contain temporal lexemes proper but its temporal semantics is understandable due to the sentence "I'm typing this just by the window, looking out to the blue-gray sea, where three gulls are diving into the water".

The translatological analysis of the excerpt provides evidence to the relevance of multistep translation algorithm that encompasses proper identification of the ST message, careful analysis of the ST language devices and adequate transfer of their meaning into the TT 
while taking into account the cultural context. The approach emphasizes the importance of considering cognitive issues as the basis for language expressive means, thus focusing on the proper choice of linguistic means of the TL in the translation process.

Conclusions. The importance of research of linguistic means that are involved in the reconstruction of the ST message in the TT to convey the ST semantics and pragmatics adequately, leads to the necessity to consider particularities of the interpretative cognitive approach to the transfer of the ST general content to ensure accurate transfer of its message.

Significant attributes of culture in all its manifestations should be regarded as an integral part of the literary text translation, as they convey the uniqueness of 'otherness' and help meet the cognitive and aesthetic needs of the target culture; it is through literary translation that values of the original culture are transferred into the context of target language and culture. The role of cognitive translatology resulted in designing the interpretative cognitive approach in current translation studies that aim at the research of the ways concepts are actualized in different cultural settings.

The necessity to elaborate on major theoretical postulates of current translation studies was highlighted so that to enhance further research of numerous linguistic devices and make meaningful choice of translation strategies and techniques to transfer the ST message in the TT by a system of language means that convey its semantics and pragmatics. Translation process should encompass several procedures that consider the particularities of knowledge structures and formats, verbalized in the literary narrative, and to analyze its socio-cultural and conceptual dimensions properly as the alternative world model of the narrative calls for accurate interpretation and correct translation choices to transfer both the narrative content and its particular pragmatic and semantic characteristics adequately.

\section{References:}

1. Baker M. In Other Words: A Coursebook on Translation. 2-nd edition. Routledge, 2011. $352 \mathrm{p}$.

2. Chugu S. Cognitive, Pragmatic and Interpretative Dimensions of Narrative Texts in Current Translation Studies. Молодий вчений. 2020. № 2.1 (78.1). P. 94-97.

3. Coulson S., Todd O. Blending and coded meaning: Literal and figurative meaning in cognitive semantics. Journal of Pragmatics. 2005. Vol. 37. P. $1510-1536$.

4. Derrida J. What is a "relevant" translation? Critical Inquiry. 2001. № 27 (2). P. 174-200.

5. Doloughan F.J. Contemporary Narrative: Textual Production, Multimodality and Multiliteracies. London : Continuum, 2011. 168 p.

6. Fauconnier G., Turner M. The Way We Think: Conceptual Blending and the Mind's Hidden Complexities. New York : Basic Books, 2002. $464 \mathrm{p}$.

7. Hansen G. Success in translation. Perspectives. Studies in Translatology. 2010. Vol. 5 (2). P. 201-210.

8. Pym A. Exploring Translation Theories. $2^{\text {nd }}$ edition. London : Routledge, 2014. $192 \mathrm{p}$.

9. Rebrii O. Systemic Approach to Translation: Experimental Research. Advanced Education. 2017. Vol. 8. P. 109-114.

10. Shields K. Challenges and Possibilities for World Literature, Global Literature, and Translation. Comparative Literature and Culture. 2013. Vol. 15/7. P. 2-9.

11. Smith Z. Swing Time. New York : Penguin Press, 2016. 425 p.

12. Tkachuk T. Realia types and strategies of their translation in frames of cultural translation. International Humanitarian University Herald. Philology. Odessa. 2017. Vol. 2. Issue 30. P.105-107.
13. Toury G. Probabilistic Explanations in Translation Studies: Universals - Or a Challenge to the Very Concept? Translation universals: Do they exist? Amsterdam, Philadelphia : John Benjamins, 2004. V. 48. P. $15-32$.

14. Zhabotynska S., Slyvka N. Emotive speech acts and their discourse modifications in the literary text. Discourse and Interaction. 2020. Vol. 13 (1). P. 113-136.

Чугу С. Д. Переклад неперекладних елементів художнього тексту: інтерпретаційний вимір

Анотація. У статті розглядаються особливості й переваги новітніх дослідницьких підходів до перекладу художніх текстів, пропонованих у межах когнітивної парадигми, та обгрунтовується доцільність використання інтерпретативно-когнітивного підходу в художньому перекладі. Інтерпретативна модель перекладу базується на теоретичних постулатах когнітивної науки та інкорпорує напрацювання низки сучасних наукових напрямів, що сприяє досягненню поглибленого розуміння глибинних когнітивних процесів кодування інформації в тексті оригіналу й окреслює шляхи ii декодування в тексті перекладу шляхом використання низки дієвих перекладацьких стратегій і тактик.

Важливість правильної інтерпретації культурно-специфічних концептів і реалій у перекладах творів прозового жанру детермінована необхідністю подальшого вивчення механізму віддзеркалення особливостей сприйняття й осмислення дійсності певною мовною спільнотою, що зумовлено особливостями категоризації світу представниками певної етнокультури. Репрезентації структурованих знань у художній моделі світу виявляються в єдності мовного й концептуального аспектів, прагматичне навантаження мовних засобів пропонується аналізувати через призму когнітивно-прагматичного підходу з урахуванням результатів міждисциплінарних студій.

Автор наголошує на важливості збереження характерних ознак тексту оригіналу в ході його семантичної та прагматичної модифікації для досягнення адекватної трансляції його змісту й забезпечення естетично-літературного сприйняття. Інтерпретативно-когнітивний переклад тлумачиться як алгоритм певних перекладацьких дій, що включає систему спеціальних стратегій і прийомів перекладу, спрямованих на правильну лінгвальну репрезентацію концептуального виміру художнього тексту. Доведено, що врахування в сучасних транслятологічних розвідках закономірностей конструювання й реконструювання ментальних конструктів у ході перекладу тексту уможливлює вибір інтерпретаційних інструментів, що забезпечують правильне сприйняття прагматичних налаштувань і літературно-естетичних рис тексту оригіналу.

Застосування комплексного інтерпретаційно-когнітивного підходу до аналізу художнього тексту доводить наявність у текстовому просторі кількох моделей альтернативного світу, одним із базових вимірів яких є темпоральний параметр, представлений різними пластами, що характеризуються певними соціокультурними ознаками. Установлення особливостей вербалізації концептуальних властивостей тексту уможливлює правильну інтерпретацію їх прагматичного навантаження та вивчення впливу семантики окремих мовних одиниць на актуалізацію різних форматів знання в текстовому просторі, виходячи з потрактування концептуального виміру художнього тексту як джерела актуалізованого конвенційного знання певної мовної спільноти.

Ключові слова: інтерпретативно-когнітивний підхід, художній текст, когнітивний вимір, культурний концепт, модель світу тексту, перекладацька стратегія. 